\title{
Menthol sensory qualities and smoking topography: a review of tobacco industry documents
}

\author{
Valerie B Yerger, ${ }^{1,2}$ Phyra M McCandless ${ }^{2}$
}

${ }^{1}$ Department of Social and Behavioral Sciences, University of California, San Francisco, San Francisco, California, USA ${ }^{2}$ Center for Tobacco Control Research and Education, University of California, San Francisco, San Francisco, California, USA

\section{Correspondence to} Dr Valerie B Yerger, Department of Social and Behavioral Sciences, University of California, San Francisco, Box 0612, San Francisco, CA 94143-0612, USA: valerie.yerger@ucsf.edu

This manuscript will be useful for the Tobacco Control readership in all countries that are parties to the FCTC, as they implement the product regulation provisions of the FCTC

Received 17 November 2010 Revised 11 January 2011 Accepted 23 January 2011

\section{(2) UNLOCKA}

This paper is freely available online under the BMJ Journals unlocked scheme, see http:// tobaccocontrol.bmi.com/site/ about/unlocked.xhtml

\section{ABSTRACT}

Objective To determine what the tobacco industry knew about the potential effects of menthol on smoking topography-how a person smokes a cigarette.

Methods A snowball strategy was used to systematically search the Legacy Tobacco Documents Library (http://legacy.library.ucsf.edu) between 1 June 2010 and 9 August 2010. We qualitatively analysed a final collection of 252 documents related to menthol and smoking topography.

Results The tobacco industry knew that menthol has cooling, anaesthetic and analgesic properties that moderate the harshness and irritation of tobacco. Owing to its physiological effects, menthol contributes to the sensory qualities of the smoke and affects smoking topography and cigarette preference.

Conclusion Our review of industry studies suggests that the amount of menthol in a cigarette is associated with how the cigarette is smoked and how satisfying it is to the smoker. If menthol in cigarettes was banned, as the US Food and Drug Administration (FDA) is currently considering, new/experimental smokers might choose not to smoke rather than experience the harshness of tobacco smoke and the irritating qualities of nicotine. Similarly, established menthol smokers might choose to quit if faced with an unpleasant smoking alternative.

\section{INTRODUCTION}

In the USA the 2009 Family Smoking Prevention and Tobacco Control Act gave the US Food and Drug Administration (FDA) regulatory authority over tobacco products. On 22 September 2009, the FDA exercised this authority by prohibiting cigarette manufacturers from adding artificial or natural flavours other than tobacco or menthol to cigarettes. Menthol's protected status was controversial among some in the public health arena, ${ }^{1}$ who noted that menthol is disproportionately marketed to African Americans. ${ }^{2}{ }^{3}$ Currently in the USA, $83 \%$ of African American smokers consume mentholated cigarettes (compared with $32 \%$ of Hispanic smokers and $24 \%$ of white smokers). ${ }^{4}$ Mentholated cigarettes are also actively promoted in other parts of the world and make up a substantial proportion of the market in many countries. ${ }^{5-7}$

The popularity of menthol is due, in part, to its minty flavour, aroma and its sensory effects on the smoker. $^{8-13}$ Some menthol smokers specifically seek out the flavour and associated cooling sensation; others seek to reduce the harshness and irritation associated with smoking non-mentholated cigarettes. ${ }^{11}$ Menthol's cooling characteristics, which come from its ability to stimulate cold receptors, ${ }^{14}{ }^{15}$ improve the taste of tobacco for some smokers. ${ }^{16}{ }^{17}$ The cooling effect of menthol leads smokers to perceive a reduction of harshness of smoke. ${ }^{11}$ Kreslake et a ${ }^{18}$ showed that the cigarette manufacturers used their knowledge of menthol's sensory qualities and manipulated the menthol content of cigarettes to attract adolescents and young adults, thereby facilitating smoking initiation and nicotine dependence.

A number of factors collectively account for smoking topography (how a person smokes a cigarette). Smoking topography is measured by the number of puffs, puff volume and frequency of puffs. How deeply one inhales, how long one holds smoke in the lungs and how much of the cigarette the smoker smokes are also parameters of smoking topography. ${ }^{19}$ It has been posited that menthol's cooling and anaesthetic effects may affect the intensity of how cigarettes are smoked, such as increased number of puffs, deeper inhalation and longer retention of smoke in the lungs. ${ }^{8} 102021$ Several smoking studies examining the relation between mentholation and smoking topography have been published in the open literature; ${ }^{82-26}$ however, findings have been mixed ${ }^{27}$ as menthol has been shown to increase and decrease either puff volume, puff count or depth inhalation.

What the industry understands about menthol's sensory effects, its mechanisms of action and its ability to reduce the irritation and harshness of smoking already have been described in articles published in the open literature. ${ }^{10-12} 18$ This paper analyses publicly available internal tobacco industry documents to determine what the industry knows about the effects of the sensory qualities of menthol on smoking topography, and the implications for public health.

\section{METHODS}

We searched previously secret internal tobacco industry documents in the Legacy Tobacco Documents Library (LTDL) (http://legacy.library.ucsf edu) between 1 June 2010 and 9 August 2010 using snowball sampling in which previous searches inform subsequent searches ${ }^{28-31}$ as described in detail by Anderson et al. ${ }^{28}$ Our initial keyword searches combined terms related to: menthol, topography, smoking behaviour, menthol yield, menthol intensity, inhaled volume and carbon monoxide level. This initial set of keywords resulted in the development of further search terms and combinations of keywords (eg, depth inhalation, puff number, puff volume, bustle-injected, menthol release agent). We analysed a final collection of 252 documents, of which 37 were representative and cited in this paper. 


\section{RESULTS}

\section{Menthol sensory properties contribute to smoking experience}

Menthol has sensory properties that affect how a person smokes a cigarette. Key descriptions of menthol's properties that appear in reports by Brown \& Williamson (B\&W) in 1972 and the Roper Organization (for Philip Morris) in 1979 include 'cooling effect', 'irritation', 'analgesia', 'amelioration' and 'slightly numbing, anaesthetic effects'. 32 33 Menthol also has analgesic, or pain reducing, properties. In a 1972 memo, ${ }^{32}$ a B\&W researcher described menthol's analgesic properties:

\begin{abstract}
Menthol in cigarette smoke is a local analgesic in that it apparently and/or absolutely reduces the intensity of tobacco pain-suggestive sensations in the mouth, throat, and nose. It is not known whether smoke menthol acts as a drug-like analgesic (reversibly impeding nerve impulse transmission) or as a 'mental analgesic' (causing reversible loss of ability to recognise or identify pain sensations) or as both (emphasis in original). ${ }^{32}$
\end{abstract}

These sensory properties of menthol make cigarettes more palatable and easier to smoke than non-mentholated cigarettes. ${ }^{34}$ One of the concluding remarks made by Creative Research Group in its 1982 'Project Crawford' report presented to the Imperial Tobacco Company, succinctly states how menthol's properties affect the smoking experience:

\begin{abstract}
The whole smoking experience, for the committed menthol smoker, thus becomes much more pleasant. Negatives are minimised (tobacco taste and harshness); positive attributes are superimposed (coolness and menthol taste). In fact, given the menthol smoker's explanation, it becomes difficult to understand why everyone would not switch to a menthol brand! ${ }^{34}$
\end{abstract}

In 1984-5, the RJ Reynolds Sensory Evaluation Division conducted an internal review of the open literature on the physiological effects of menthol and presented its findings in its report, 'Menthol and the design of mentholated cigarettes'. ${ }^{35}$ This report and two published articles written by tobacco industry researchers ${ }^{36} 37$ provide evidence that cigarette companies knew, not only from their own internal studies but also from monitoring studies published in the open literature, that menthol has cooling and anaesthetic properties that moderate the harshness and irritation of tobacco and affect how cigarettes are smoked. ${ }^{38}$

\section{Taste versus sensory effects}

Taste is important to the industry because the viability of their products in the market depends on taste. A 1978 memo from market researchers at the Roper Organization to Philip Morris' marketing and consumer research departments addressed menthol properties: '(M)eeting confirmed certain theses that we had-that there are physiological effects from menthol, and that the taste of a menthol cigarette lasts longer than that of a non-menthol'. 39

The following year, the Roper Organization conducted a focus group study for Philip Morris 'with a special emphasis on low tar and menthol cigarettes ${ }^{\prime 33}$ to assess the menthol market in terms of usage and smokers' attitudes. The study consisted of interviews with 1367 adult smokers, with an oversample of menthol smokers. Results revealed

( $\mathrm{T})$ here were no unique or distinctive taste preferences that distinguish menthol smokers from other smokers-aside from their liking for menthol. What differences exist in taste preferences are either minor or contradictory or both...the appeal of menthol cigarettes is more in terms of their (sensory) effects than their tastes. $^{33}$
Another line of evidence is from an internal 1981 document, found in the files of a Philip Morris marketing vice president, and revealed taste may be indistinguishable from a primary menthol sensory effect: 'Four key menthol taste effects that appeal to smokers are cooling, clean/antiseptic, numbing/anaesthetic, refreshing'; noting in particular, 'menthol is a 'sensation' in which menthol taste and cooling are indistinguishable'. ${ }^{40}$

A 1987 B\&W memorandum, titled 'Kool Isn't Getting the Starters', from DV Cantrell at B\&W to I D Macdonald, B\&W marketing vice president, provides evidence that the tobacco industry knew that low levels of menthol attracted younger, inexperienced smokers, who prefer the candy-like taste of menthol. ${ }^{41}$ This B\&W document was also cited by US district court judge Gladys Kessler in her 2006 ruling finding the industry liable for civil fraud and racketeering as evidence of the tobacco industry promoting its products to youths. ${ }^{42}$

\section{Masking effects}

Menthol's ability to 'undeniably impart a cooling influence, 34 reduces both the harshness and taste of tobacco. In 1976, RJ Reynolds confidentially reported on taste tests conducted to see if low or subliminal levels of menthol would enhance smoke quality. ${ }^{43}$ Menthol was added to RJ Reynolds' non-mentholated brand Winston to deliver $1-2 \mu \mathrm{g}$ of menthol per puff. (RJ Reynolds' mentholated brand Salem delivers $45 \mu \mathrm{g}$ of menthol/ puff.) Although smokers did not detect the menthol, they did notice a reduction in nasal sting, tongue bite and harshness, which demonstrated menthol's non-flavour-related effects on unfavourable aspects of smoking cigarettes. Smokers participating on smoke panels for British American Tobacco (BAT) in 1979 reported that the test prototype cigarette with 'strong menthol intensity throughout' masked tobacco flavour. ${ }^{44}$ In 1984, RJ Reynolds' chemical and sensory evaluation research team also demonstrated that menthol moderated the negative sensations, such as the irritation, that come with smoking tobacco. $^{45}$

In a 1992 focus group study, Philip Morris collected data to be used for developing a new Benson \& Hedges brand menthol product. Participants 'seem(ed) to like menthol because it buffers/ masks the taste of tobacco. ${ }^{46}$ Participants made a distinction between inhaling and exhaling mentholated cigarettes. ${ }^{46}$ They perceived inhaling a menthol cigarette to be 'cool' or 'minty', and that the 'rush' of menthol was more pronounced during inhalation, but also noted that inhaling cigarettes with too much menthol elicited a 'bite' that actually hurt. ${ }^{46}$ In contrast, the participants perceived the sensation of exhaling mentholated cigarettes to be 'less about the menthol taste and more about the absence of cigarette taste'. ${ }^{46}$ They reported that it is during the exhalation phase that menthol masks the taste of tobacco, making the smoke 'smoother'. ${ }^{46}$ Philip Morris decided that 'further exploration of positive ways to leverage this masking effect may be warranted' (emphasis in original). ${ }^{46}$

\section{Menthol affects smoking topography parameters}

Sensory cues contribute to how a cigarette is smoked, and ultimately relate to the yield of a variety of smoke constituents in the puff. ${ }^{47}$ No two smokers smoke precisely the same way or even the same way all the time. ${ }^{47-49}$ Smoking parameters range from $20 \mathrm{~cm}^{3}$ to $80 \mathrm{~cm}^{3}$ for puff volume, $0.8-3.0$ seconds for puff duration, $20-100$ seconds for puff interval, and $19-28 \mathrm{~mm}$ for butt length of unfiltered cigarettes. ${ }^{47}$ Smokers generally reduce their puff volume and duration as they consume the cigarette to reduce the sensory effects of yields that would otherwise increase with puff number. ${ }^{47}$ 
As part of the company's New Product Technologies (NPT) and Human Smoking Behaviour programmes, RJ Reynolds in 1990 collected data on puffing parameters to develop new products and, secondly, analysed the data to examine the effects of nicotine and menthol levels upon smoking behaviour. ${ }^{50}$ The following is a list and description of the smoking topography parameters, provided by RJ Reynolds' researchers working in these programmes. ${ }^{50}$

- Mean and peak pressure...how hard the subject is drawing on the cigarette. Mean is the average over a puff, and peak is the maximum.

- Flow rate...the rate of airflow through the mouth end of the cigarette.

- Puff duration...how long (in seconds) the subject draws on the cigarette during a puff.

- Puff volume...the volume of air that flows through the mouth end of the cigarette during the puff.

- Number of puffs...simply the number of distinct puffs the subject takes while smoking the cigarette.

- Total puff volume...the total volume of air that flows through the mouth end of the cigarette during all puffs of the cigarette smoking. It is simply the sum of the puff volumes of each puff.

- Cycle time...the length of time in seconds from the beginning of a puff until the beginning of the next puff.

- Static time...the length of time in seconds from the end of a puff until the beginning of the next puff.

- Frequency...the reciprocal of cycle time, expressed in puffs per minute.

In studies comparing its mentholated NPT products with its established mentholated brands Salem Light and Now Menthol, RJ Reynolds found products with a menthol level not too low and not too high would be the most satisfying to a smoker. ${ }^{50}$ Salem Light contained a higher amount of nicotine and menthol than Now Menthol, which had a medium level of nicotine and low level of menthol when compared to the test NPT products (see table 1). There were a number of NPT prototypes, each with varying ratios of nicotine and menthol. Topography parameters were collected and the number of puffs was noted. The number of puffs, according to RJ Reynolds, suggested how well liked a cigarette is or how satisfied the smoker is with the mentholated product. RJ Reynolds noted that when a mentholated cigarette is associated with fewer puffs, the smoker is more likely to accept a cigarette and be satisfied by it. ${ }^{50}$ The results from this study suggest the relation between nicotine and menthol affects how a cigarette is smoked and how the smoker perceives the smoking experience of that cigarette.

By 1974, Philip Morris had conducted several internal menthol smoker simulation studies, collecting data on smoking topography parameters such as puff count, puff volume (cc), flow (cc) $\mathrm{min})$, puff duration $(\mathrm{sec})$ and puff interval $(\mathrm{sec}) .{ }^{51}$ In a 1974
Table 2 Philip Morris tested Benson \& Hedges Regular and Benson \& Hedges Menthol cigarettes. Analysis of how a small test panel smoked the cigarettes demonstrated that total particulate matter (TPM), tar and nicotine levels, and puff counts were higher in the menthol cigarettes compared to the non-menthol ones. ${ }^{50}$

\begin{tabular}{lll}
\hline Benson \& Hedges Regular & Analysis & Benson \& Hedges Menthol \\
\hline 18.9 & TPM, mg/cigt. & 20.8 \\
14.9 & FTC Tar, mg/cigt. & 16.5 \\
1.14 & Micotine, mg/cigt. & 1.33 \\
1.9 & Water, mg/cigt. & 2.0 \\
8.8 & Puff Count, puffs/cigt. & 9.1 \\
4.7 & RTD, in. of $\mathrm{H}_{2} \mathrm{O}$ & 4.8 \\
& Menthol & \\
& Smoke, mg/cigt. & 0.46 \\
& Filter, mg/plug & 1.57 \\
& Rod, mg/cigt. & 1.68 \\
\hline
\end{tabular}

study conducted with six menthol smokers and six non-menthol smokers, Philip Morris researchers compared the smoking topography between the menthol and non-menthol smokers. ${ }^{51}$ The model cigarettes were Philip Morris' Benson \& Hedges Menthol and Benson \& Hedges Regular. Each subject smoked each model cigarette six times. Total particulate matter (TPM), tar and nicotine levels, and puff counts were higher in the menthol cigarettes than the non-menthol ones (table 2). The puff volumes reported in the study were associated with smokers smoking their usual cigarette type. The menthol smokers had higher puff volumes when smoking mentholated cigarettes, whereas the non-menthol smokers had higher puff volumes when smoking non-mentholated cigarettes.

A few years later, Philip Morris researchers noted that menthol smokers smoked their usual menthol brand differently from the way they smoked other mentholated brands. ${ }^{52}$ In its 'Smoker Response Study of Competitive Menthol Brands', 52 Philip Morris found that smokers who regularly smoked the Philip Morris menthol brand took more puffs, had higher puff volume and took puffs of longer duration on their regular brand than they did while test smoking the Kool brand. Consistent with findings from earlier studies, Philip Morris researchers concluded that when smoking their usual mentholated brand, menthol smokers experienced higher puff counts, puff volume and puffs of longer duration. Later in a 1999 confidential document titled 'Menthol Allegations', Philip Morris did not report findings from its earlier studies on menthol and smoking topography parameters. Rather than cite its earlier findings that the way menthol smokers smoke is influenced by what they smoke, Philip Morris focused on the studies published in the open literature, which presented findings that were inconclusive and at times conflicting. Philip Morris concluded from its analysis of the published literature that menthol's effect on smoking

Table 1 Varying nicotine and menthol levels in a 1990 RJ Reynolds human smoking behaviour study influenced the smoking experience, but old products were preferable to new products. ${ }^{49}$

\begin{tabular}{|c|c|c|c|}
\hline Cigarette & Nicotine (mg) & Menthol (mg) & Notes \\
\hline Salem light 85 & 1.430 & 0.725 & Satisfying; easy to draw and light; menthol and cool taste \\
\hline Now menthol 85 & 0.456 & 0.410 & Satisfying; easy to draw and light; menthol taste; cool taste, aftertaste; stays lit \\
\hline NPT low nicotine/low menthol (L/L) & 0.423 & 0.263 & Menthol taste; stays lit; less harsh \\
\hline NPT low nicotine/high menthol (L/H) & 0.472 & 0.678 & Less harsh; menthol taste; cool taste and aftertaste \\
\hline NPT medium nicotine/low menthol (M/L) & 0.745 & 0.268 & Least harsh; not easy to draw or light; less satisfying \\
\hline NPT medium nicotine/medium menthol (M/M) & 0.730 & 0.449 & Less harsh; least satisfying; not easy draw or light \\
\hline NPT medium nicotine/high menthol (M/H) & 0.759 & 0.619 & Less satisfying; not easy to draw or light; menthol taste \\
\hline
\end{tabular}

The information in this table was compiled from tables II and IV in the RJ Reynolds document. ${ }^{50}$ 
topography is inconclusive owing to "the complex interplay of smokers' taste preferences, ethnicity of subject, and selection of cigarettes to be smoked under experimental conditions'. ${ }^{53}$ After over a decade of its internal studies on menthol and smoking topography, which were often conducted with small sample sizes, Philip Morris did conclude, however, that the sensory effects of menthol were among a number of factors that influenced the smoking behaviours of smokers. ${ }^{54}$

\section{Smoking topography: menthol smokers versus non-menthol smokers}

Tobacco manufacturers studied differences in smoking topography parameters between menthol products and did not appear to focus on topography differences between menthol and nonmenthol smokers. However, a study conducted in 1995 by B\&W researchers compared the post-puff inhalation volume between menthol and non-menthol smokers. The researchers did not note differences between menthol smokers and non-menthol smokers and concluded that smoking mentholated cigarettes did not increase inhalation volume (figure 1). ${ }^{55-57}$

\section{Menthol delivery affects smoking experience}

Kreslake et al presented evidence from the industry documents that menthol delivery affects the smoking experience and that there are differences not only between menthol and nonmenthol smokers, but also among menthol smokers. ${ }^{18}$ Menthol smokers are differentiated by their desire for reduced irritation or by their desire for menthol taste. Cigarette companies experimented during the 1980s and 1990s to discover the 'most desirable levels of menthol'. ${ }^{58}$ The sensory qualities differ depending on the level of menthol as well as nicotine. Levels that are unfamiliar to a smoker will affect smoking topography, making it more difficult for a smoker to smoke a new product. A balance of medium levels of menthol tends to be preferred by the smokers. For example, while testing Lorillard's Newport and other competing brands in 1981, Philip Morris found that 'smokers who perceive their cigarette as being more acceptable may also perceive that cigarette as having a medium level of menthol'. ${ }^{99}$ A paper presented at the 47th Tobacco Chemists' Research Symposium also disclosed that unless menthol ranges between $0.3 \%$ and $1.0 \%$ of tobacco weight, the cigarette would lack the minty, cooling characteristics associated with menthol. ${ }^{58}$

In 1982, RJ Reynolds tested the preferences of two age groups of women menthol smokers. ${ }^{60}$ It concluded that the younger

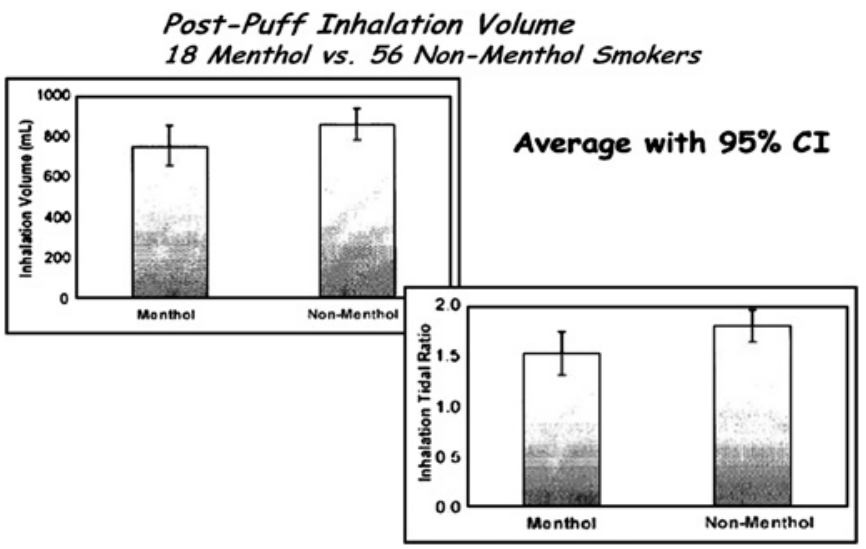

Figure 1 A Brown \& Williamson study in the Philip Morris Collection compared puff inhalation volume of menthol to the puff inhalation of non-menthol smokers and showed no difference. ${ }^{55}$ women (aged 18-34) desired more menthol sensation than the older women (aged 35+). However, this increased menthol sensation did not mean the younger women wanted more menthol. On the contrary, RJ Reynolds discovered that less absolute menthol delivery (micrograms/ puff) was needed to achieve the higher menthol sensation in the younger group: 'Age related perception differences of menthol delivery occur across all menthol cigarette brands and categories. Younger adult female smokers tend to perceive more menthol delivery than older female smokers irrespective of what brand they are smoking (emphasis in original). ${ }^{60}$

\section{Engineering mentholated cigarettes}

Menthol is highly volatile and susceptible to migration in the tobacco, which causes the menthol yield in cigarettes to fluctuate and prevents the 'strict control of quantitative releases of menthol to the tobacco smoke'. ${ }^{61}$ The volatile nature of menthol presented challenges for cigarette companies, evidenced by the number of patent applications filed to develop mentholated cigarettes that reflected the latest in technology. ${ }^{61}$ As revealed in a 1976 Liggett and Meyers interoffice memo between researcher Roy Hilliard and executive James C Turner (who became the company's executive VP and chief operating officer in 1989), the fluctuating yields of menthol presented major challenges to cigarette companies. ${ }^{62}$ Cigarette companies tried, sometimes with great difficulty, to stabilise and prevent fluctuations in the menthol yields of their mentholated cigarettes, as described in a US patent application filed in 1978 by Grubbs et al on behalf of Philip Morris. $^{61}$

In 1994, BAT sought novel approaches to stabilise menthol in their mentholated products; however, attempts to use common fixative materials such as benzyl benzoate offered no significant improvement in menthol retention by the tobacco rod or increased delivery to the smoker. ${ }^{63}$ Menthol's volatility and migration tendencies were also recognised by Philip Morris in $1982^{64}$ and Lorillard in 1990. ${ }^{65}$ For example, in his 1982 report on menthol's transfer to smoke, a Philip Morris scientist noted that the migrational properties of menthol affect the puff-by-puff menthol delivery. ${ }^{64}$

The loss of menthol was problematic not only because of menthol's migration from the cigarette rod to the filter but also because filtered menthol cigarettes were perishable products, with the storage time and storage temperature also affecting menthol delivery. ${ }^{66}$ Regardless of how menthol was applied, cigarette companies - including RJ Reynolds in 1985recognised the need to continue their investigation into the mechanism(s) by which menthol is delivered to the smoke'. ${ }^{35} \mathrm{RJ}$ Reynolds, for example, recognised that increasing the efficiency of menthol delivery could lower the amounts of menthol applied to cigarettes and that this improved usage of menthol would have 'great potential economic benefits' for the company. ${ }^{67}$

Table 3 from an undated B\&W product development report ${ }^{68}$ provides the range of menthol content and smoke menthol by brand.

During the late 1960s, 1970s and 1980s, cigarette companies paid close attention to the concepts of increased filter efficiency and ventilation (ie, diluting the smoke stream with air) in filter tips. ${ }^{35}$ Cigarette construction parameters and menthol load had an impact on the performance of mentholated cigarettes, demonstrated by an in-house study conducted in 1984 by RJ Reynolds' research and development scientists. ${ }^{35}$ They found that increasing levels of ventilation while decreasing levels of filtering efficiency would allow RJ Reynolds to design a mentholated cigarette that delivered more menthol to the smoker. 
Table 3 TAR, nicotine and menthol delivery versus CIG. menthol content $^{68}$

\begin{tabular}{llclll}
\hline BRAND & $\begin{array}{l}\text { MENTHOL } \\
\text { CONTENT } \\
(\%)\end{array}$ & $\begin{array}{l}\text { TAR } \\
\text { (mg/cig) }\end{array}$ & $\begin{array}{l}\text { NIC } \\
\text { (mg/cig) })\end{array}$ & $\begin{array}{l}\text { SMOKE } \\
\text { MENTHOL } \\
\text { (mg/cig) }\end{array}$ & $\begin{array}{l}\text { F OF } \\
\text { PUFFS }\end{array}$ \\
\hline KOOL KS & 0.42 & 17 & 1.2 & 0.50 & 6.8 \\
KOOL XL XS (Japan) & 0.34 & 9 & 0.8 & 0.24 & 7.6 \\
KOOL MILDS KS & 0.52 & 12 & 0.9 & 0.50 & 7.3 \\
KOOL DELUXE LTS KS & 0.70 & 9 & 0.8 & 0.50 & 7.8 \\
NEWPORT KS & 0.34 & 17 & 1.3 & 0.44 & 7.2 \\
SALEM KS & 0.42 & 18 & 1.4 & 0.58 & 7.3 \\
SALEM LTS KS & 0.58 & 8 & 0.7 & 0.40 & 6.9 \\
ALPINE KS & 0.42 & 17 & 1.1 & 0.46 & 7.3 \\
NOW MENTHOL KS & 1.90 & 1 & 0.2 & 0.15 & 6.3 \\
\hline
\end{tabular}

In 1968, American Tobacco's research on its menthol competitors indicated higher menthol yields came from cigarettes containing ammonium salts in reconstituted tobacco. ${ }^{69} \mathrm{~B} \& \mathrm{~W}$ (probably around 1992) noted that Philip Morris changed Marlboro Menthol to an ammoniated reconstituted tobacco to attract B\&W Kool and Lorillard's Newport menthol smokers, ${ }^{68}$ demonstrating Philip Morris willingness to modify its products to respond to their competitor's products. B\&W also observed that to facilitate non-menthol smokers switching to a menthol brand, lower menthol content was preferred over higher menthol content. ${ }^{68}$

RJ Reynolds continued testing new menthol products in the 1980s, focusing on the properties that were important to menthol cigarettes. ${ }^{70}$ The company experimented with encapsulating menthol in flavour pellets applied inside the filter, systematically varying the menthol level to determine consumer perception and acceptability. ${ }^{70}$ The higher levels of menthol were found to be related to higher perceptions of menthol coolness. In a 1990 RJ Reynolds human smoking behaviour study, test cigarettes with low levels of menthol lacked the sensory cues, menthol taste, smoothness and aroma found in cigarettes with higher delivery of menthol. ${ }^{50}$ Menthol cigarettes packaged in a box delivered a lower amount of menthol than did menthol cigarettes contained in a soft pack, as the box absorbed menthol faster. ${ }^{71}$

\section{DISCUSSION}

Our analyses of publicly available internal tobacco industry documents support the findings of Wayne et al, ${ }^{10}$ which show cigarette manufacturers have long known that menthol has cooling, anaesthetic and analgesic properties that moderate the harshness and irritation of tobacco. These menthol sensory properties make it easier for new or young smokers to consume cigarettes $^{18} 72$ and more difficult for established smokers to quit smoking. ${ }^{73}$ As one tobacco company observed in 1987, young, inexperienced smokers are attracted to menthol brands containing low levels of menthol, which provide a familiar, candy-like taste. ${ }^{41}$

Studies published in the open literature present mixed findings regarding menthol and its effect on puff volume and puff count. For example, menthol has been shown to increase puff volume, ${ }^{23}$ decrease it ${ }^{22} 2425$ or have no effect on it. ${ }^{74}$ When comparing smoking behaviours in subjects who smoked menthol cigarettes for a week followed by a week of smoking non-menthol cigarettes, McCarthy et al found subjects took fewer puffs when smoking the menthol cigarettes; ${ }^{25}$ yet Ahijevych found mentholation had no effect on the number of puffs per cigarette. ${ }^{22}$ Philip Morris found menthol smokers had a higher puff count, greater puff volume and longer puff duration when they smoked their usual menthol brand, but not when they smoked another mentholated brand. ${ }^{52}$ High levels of menthol in a cigarette, according to RJ Reynolds' research ${ }^{50}$ increased the number of puffs, which was also associated with less satisfaction for the smoker. B\&W also found that the level of menthol was associated with the number of puffs, noting specifically that medium level of menthol was associated with the smoker taking fewer puffs. ${ }^{68}$ In the open literature, menthol has been shown to increase a smoker's depth of inhalation. ${ }^{8} 102175$ This finding is not consistent with what has been reported by B\&W researchers, who found that mentholated cigarettes did not increase inhalation volume when compared to non-mentholated cigarettes. ${ }^{56}$

It is difficult to compare results from studies published in the open literature with findings from tobacco industry internal studies because the tobacco manufacturers studied differences in smoking topography parameters between menthol products, varying the levels of menthol and nicotine. Our examination of tobacco industry research on menthol sensory qualities suggests that tobacco manufacturers were more concerned with how to compete with other brands than they were with determining how these sensory qualities may affect the smoking experience of menthol smokers differently from smokers of non-mentholated cigarettes. A limitation in our study is that the industry might have done this research, but the documentary evidence may not have been used in any litigation and is therefore not in the LTDL.

Our research shows the tobacco companies understand that menthol plays a crucial part in making cigarettes easier to smoke, even in cigarettes with subliminal and undetected levels of menthol, ${ }^{43}$ which demonstrates that menthol's non-flavourrelated effects decrease unfavourable aspects of smoking cigarettes. Since all cigarettes have a small amount of menthol in them, ${ }^{6}$ this finding suggests that banning menthol, as the US Food and Drug Administration (FDA) is currently considering, would have a positive impact on smokers of 'non-mentholated' cigarettes as well as smokers of mentholated cigarettes in terms of encouraging smoking cessation and reducing smoking uptake.

Because menthol affects the smoking experience and 'helps the poison go down easier ${ }^{76}$ menthol contributes to the overall burden of illness and death caused by tobacco products. How one responds to an early smoking experience has an important

\section{What is already known on this topic}

Menthol is widely used as a flavour additive in cigarettes, yet the tobacco industry knows menthol has cooling and anaesthetic properties that reduce the harshness and irritation that come with smoking non-mentholated cigarettes.

\section{What this study adds}

The available industry documents suggest that tobacco companies know that the relation between menthol and nicotine levels has a crucial role in making cigarettes easier to smoke, even in cigarettes with subliminal and undetected levels of menthol, which demonstrates that menthol's non-flavour-related effects decrease unfavourable aspects of smoking cigarettes. 
role in determining who becomes a smoker. Menthol's sensory and physiological effects make it more likely that this early smoking experience will be a positive one and that a new smoker will become an established smoker. ${ }^{77}$ If menthol cigarettes were banned, new/experimental smokers might choose not to smoke rather than experience the harshness of tobacco smoke and the irritating qualities of nicotine. Similarly, established menthol smokers might choose to quit if faced with an unpleasant smoking alternative. This would then decrease smoking initiation and encourage cessation.

Acknowledgements I thank Stanton Glantz, Patricia McDaniel and Elizabeth Smith for their valuable insights and support in developing this paper. I thank Kim Klausner for her assistance in searching the LTDL and data management, and Vera Harrell for her administrative assistance.

Funding Supported by the Department of Health and Human Services Contract HHSN261201000035I, California Tobacco-Related Disease Research Program, Grant \#16RT-0149, and National Cancer Institute grant CA113710-05. Staff from the Food and Drug Administration offered comments on the original white paper. Neither the FDA nor the $\mathrm{NCl}$ played any role in the decision to publish or in preparation of this manuscript for submission to Tobacco Control.

\section{Competing interests None}

Provenance and peer review Not commissioned; externally peer reviewed. This peer reviewed paper is based on a longer, more detailed (but not peer reviewed) white paper prepared for the US Food and Drug Administration. The full white paper is available at http://www.escholarship.org/uc/item/25c2f5md and http://www.fda. gov/downloads/AdvisoryCommittees/CommitteesMeetingMaterials/ TobaccoProductsScientificAdvisoryCommittee/UCM228128.pdf.

\section{REFERENCES}

Mitka M. FDA exercises new authority to regulate tobacco products, but some limits remain. JAMA 2009;302:2078, 2080-1.

2. Gardiner PS. The African Americanization of menthol cigarette use in the United States. Nicotine Tob Res 2004;6(Suppl 1):S55-65.

3. Yerger VB, Przewoznik J, Malone RE. Racialized geography, corporate activity, and health disparities: tobacco industry targeting of inner cities. J Health Care Poor Underserved 2007:18(4 Suppl):10-38.

4. Substance Abuse and Mental Health Services Administration, Office of Applied Studies. The NSDUH Report: Use of Menthol Cigarettes. Rockville, MD: Substance Abuse and Mental Health Services Administration, 2009.

5. Connolly GN, Behm I, Osaki Y, et al. The impact of menthol cigarettes on smoking initiation among non-smoking young females in japan. Int J Environ Res Public Health 2011:8:1-14.

6. Giovino GA, Sidney S, Gfroerer JC, et al. Epidemiology of menthol cigarette use. Nicotine Tob Res 2004;6(Suppl 1):S67-81.

7. King B, Yong HH, Borland R, et al. Malaysian and Thai smokers' beliefs about the harmfulness of 'light' and menthol cigarettes. Tob Control 2010;19:444-50.

8. Ahijevych K, Garrett BE. Menthol pharmacology and its potential impact on cigarette smoking behavior. Nicotine Tob Res 2004;6(Suppl 1):S17-28.

9. Anderson SJ. Marketing of menthol cigarettes and consumer perceptions: A review of tobacco industry documents. Tobacco Control 2011;20(Suppl 2):ii20-ii28.

10. Ferris Wayne G, Connolly GN. Application, function, and effects of menthol in cigarettes: a survey of tobacco industry documents. Nicotine Tob Res 2004:6(Suppl 1):S43-54.

11. Kreslake JM, Wayne GF, Connolly GN. The menthol smoker: tobacco industry research on consumer sensory perception of menthol cigarettes and its role in smoking behavior. Nicotine Tob Res 2008;10:705-15.

12. Kreslake JM, Yerger VB. Tobacco industry knowledge of the role of menthol in chemosensory perception of tobacco smoke. Nicotine Tob Res 2010;12:S98-S101.

13. Yerger VB. Menthol's potential effects on nicotine dependence: A tobacco industry perspective. Tobacco Control 2011;20(Suppl 2):ii29-ii36.

14. Eccles R. Menthol and related cooling compounds. J Pharm Pharmacol 1994;46:618-30.

15. Gelal A, Jacob P 3rd, Yu L, et al. Disposition kinetics and effects of menthol. Clin Pharmacol Ther 1999:66:128-35.

16. Levin ED, Behm F, Rose JE. The use of flavor in cigarette substitutes. Drug Alcohol Depend 1990;26:155-60

17. Okuyemi KS, Ahluwalia JS, Ebersole-Robinson M, et al. Does menthol attenuate the effect of bupropion among African American smokers? Addiction 2003;98:1387-93.

18. Kreslake JM, Wayne GF, Alpert HR, et al. Tobacco industry control of menthol in cigarettes and targeting of adolescents and young adults. Am J Public Health 2008;98:1685-92

19. Collins CC, Epstein DH, Parzynski CS, et al. Puffing behavior during the smoking of a single cigarette in tobacco-dependent adolescents. Nicotine Tob Res 2010;12:164-7.
20. Brooks DR, Palmer JR, Strom BL, et al. Menthol cigarettes and risk of lung cancer Am J Epidemiol 2003;158:609-16; discussion 617-20

21. Garten S, Falkner RV. Role of mentholated cigarettes in increased nicotine dependence and greater risk of tobacco-attributable disease. Prev Med 2004;38:793-8.

22. Ahijevych K, Gillespie J, Demirci M, et al. Menthol and nonmenthol cigarettes and smoke exposure in black and white women. Pharmacol Biochem Behav 1996;53:355-60.

23. Ahijevych K, Parsley LA. Smoke constituent exposure and stage of change in black and white women cigarette smokers. Addict Behav 1999;24:115-20.

24. Jarvik ME, Tashkin DP, Caskey NH, et al. Mentholated cigarettes decrease puff volume of smoke and increase carbon monoxide absorption. Physiol Behav 1994;56:563-70

25. McCarthy WJ, Caskey NH, Jarvik ME, et al. Menthol vs nonmenthol cigarettes: effects on smoking behavior. Am J Public Health 1995:85:67-72.

26. Moolchan ET, Hudson DL, Schroeder JR, et al. Heart rate and blood pressure responses to tobacco smoking among African-American adolescents. J Natl Med Assoc 2004;96:767-71.

27. Lawrence D, Rose A, Fagan $P$, et al. National patterns and correlates of mentholated cigarette use in the United States. Addiction 2010;105(Suppl 1): 13-31.

28. Anderson SJ, McCandless PM, Klausner K, et al. Tobacco documents research methodology. Tobacco Control 2011;20(Suppl 2):ii8-ii11.

29. Malone RE, Balbach ED. Tobacco industry documents: treasure trove or quagmire? Tob Control 2000;9:334-8.

30. Miles MB, Huberman AM. Qualitative Data Analysis: An Expanded Sourcebook. 2nd ed. Thousand Oaks: Sage Publications, 1994.

31. Bero L. Implications of the tobacco industry documents for public health and policy. Annu Rev Public Health 2003;24:267-88.

32. Deines W. Terms Describing Menthol Subjective Smoke Quality: Brown \& Williamson 1972. http://legacy.library.ucsf.edu/tid/opb33f00.

33. Roper Organization. A Study of Smoker's Habits and Attitudes With Special Emphasis on Low Tar and Menthol Cigarettes Volume I. Philip Morris, 1979. http:// legacy.library.ucsf.edu/tid/tss75e00.

34. Project Crawford: Phase I: 7 Group Discussions: British American Tobacco, 1982 http://legacy.library.ucsf.edu/tid/raf36a99.

35. Perfetti TA, Savoca MR. Menthol and the Design of Mentholated Cigarette Course: RJ Reynolds, 1984. http://legacy.library.ucsf.edu/tid/syr97c00.

36. Heck JD. A review and assessment of menthol employed as a cigarette flavoring ingredient. Food Chem Toxicol 2010;48(Suppl 2):S1-38

37. Werley MS, Coggins CR, Lee PN. Possible effects on smokers of cigarette mentholation: a review of the evidence relating to key research questions. Regul Toxicol Pharmacol 2007;47:189-203.

38. Menthol in Cigarettes: British American Tobacco, No Date. http://legacy.library.ucsf edu/tid/wku50a99.

39. Roper B, Wilkins S. Cigarette Study: Philip Morris, 1978. http://legacy.library.ucsf. edu/tid/qsv28e00.

40. Learning: Philip Morris, 1981. http://legacy.library.ucsf.edu/tid/qpa11b00.

41. Cantrell D. Kool isn't Getting the Starters/236. Brown \& Williamson, 1987. http:// legacy.library.ucsf.edu/tid/gas01f00.

42. United States v: Philip Morris, 449 F. Supp. 2d 1, pp. 1050-1 (D.D.C. 2006), aff'd 566 F.3d 1095 (D.C.Cir. 2009), cert. denied, 130 S.Ct.3501, 2010.

43. Stowe ME. Quarterly Section Research Report: RJ Reynolds, 1976. http://legacy. library.ucsf.edu/tid/tzu68d00.

44. Backhurst JD. Smoke Panel Results: (Test Numbers OSP 1857-1861): British American Tobacco, 1979. http://legacy.library.ucsf.edu/tid/dpq67a99.

45. Perfetti TA, Needs KA, Mereschak CJ, et al. 7485- Sensory Evaluation Studies With Marketing Development Department. Development of a Common Language Between Consumer Attributes and Sensory Responses: RJ Reynolds, 1984. http://legacy. library.ucsf.edu/tid/piy09d00.

46. Menthol Cigarettes (Qualitative): Philip Morris, 1992. http://legacy.library.ucsf.edu/ tid/eep83e00.

47. Evaluation of Menthol for use as a Cigarette Ingredient: Philip Morris, 2001. http:// legacy.library.ucsf.edu/tid/nox75a00.

48. Objective: To Determine if There are Differences in Smoking Behavior (the Way Smokers Smoke a Cigarette) Among Different Groups of Full Flavor Non-Menthol 85 Smokers With Different Wants: RJ Reynolds, 1988. http://legacy.library.ucsf.edu/tid/ nei34d00.

49. Menthol: Lorillard, 2002. http://legacy.library.ucsf.edu/tid/avw35b00.

50. RJ Reynolds. NPT Menthol Human Smoking Behavior Basic Learning Study Research, 1990. http://legacy.library.ucsf.edu/tid/igv46b00.

51. Kiritsis GC, Osmalov JS. Smoker Simulation Studies 730500-740500: Philip Morris 1974. http://legacy.library.ucsf.edu/tid/vsw71f00.

52. Arthur R. Smoker Responses to Competitive Menthol Brands Versus Smoker Responses to Their Regular Brands: Philip Morris, 1980. http://legacy.library.ucsf.edu/ tid/tro80b00.

53. Menthol Allegations: Philip Morris, 1999. http://legacy.library.ucsf.edu/tid/hhe95c00

54. Adams CR, Walk RA. Response to CDC Director: Philip Morris, 2003. http://legacy. library.ucsf.edu/tid/bsk07a00

55. Appleton S, Krautter G, Mariner D, et al. Inhalation Volume in Smokers of Different Tar Delivery Cigarettes: Philip Morris, 1995. http://legacy.library.ucsf.edu/tid/ bdg93g00. 
56. St Charles K. Smoking Behavior Comparisons Between Menthol and Non-Menthol Smokers: Lorillard, 2005. http://legacy.library.ucsf.edu/tid/eyw35b00.

57. Charles, et al: Philip Morris, 2009. Pdf. http://legacy.library.ucsf.edu/tid/wuy81g00

58. Best FW, Borgerding MF, Borschke AJ, et al. Recent Advances in Tobacco Science Volume 19 Highlights of Current Research on Tobacco and Tobacco Chemistry Proceedings of a Symposium Presented at the 47th Meeting of the Tobacco Chemists' Research Conference 931018-931021: Lorillard, 1993. http://legacy.library.ucsf.edu/ tid/kbo01e00.

59. Ennis D, Friedel C. Newport Mapping: Philip Morris, 1981. http://legacy.library.ucsf. edu/tid/tzs62e00

60. Lawson JL. Menthol Leve/-Preference by Women Age Groups: RJ Reynolds, 1982. http://legacy.library.ucsf.edu/tid/gpp19d00.

61. Grubbs HJ, Johnson WR, van Auken TV. Flavourant-Release Resin Compositions: British American Tobacco, 1978. http://legacy.library.ucsf.edu/tid/vib66a99.

62. Hilliard R. Effect of Paper Porosity on Menthol Yield: Liggett \& Myers, 1976. http:// legacy.library.ucsf.edu/tid/etp47a00.

63. BAT Group Technical Program: Research, 1900. http://legacy.library.ucsf.edu/tid/ rgk46b00.

64. Daylor FL, Ikeda RM, Meyer LF. 2306-Flavor Component Evaluation a Review on Menthol Cigarettes-Migration of Menthol and its Transfer to Smoke: Philip Morris, 1982. http://legacy.library.ucsf.edu/tid/kjp08e00.

65. Chapman JJ. Project Proposal For Chemically Attaching Sidestream or Mainstream Flavorants to the Backbone of Selective Polymers to Enhance the Chemical Stability, Reduce Volatility, and Increase the Shelf Life of Otherwise Unstable Flavorants: Lorillard, 1990. http://legacy.library.ucsf.edu/tid/nuj30e00.

66. Perfetti TA. Review of Factors Affecting Menthol Migration and Smoke Menthol Transfer: RJ Reynolds, 1981. http://legacy.library.ucsf.edu/tid/fko33d00.
67. Norman AB, Perfetti TA, Poe ME, et al. The Effects of Cigarette Construction Parameters and Menthol Load on Menthol Cigarette Performance. 1030Menthol Matrix Program: RJ Reynolds, 1984. http://legacy.library.ucsf.edu/tid/ kim97g00.

68. Cantrell D. Brown and Williamson. Product Development Report: Brown \& Williamson No Date. http://legacy.library.ucsf.edu/tid/xfi41f00.

69. Coty ON. Analysis of RC-ATC and Competing Brands: American Tobacco, 1968. http://legacy.library.ucsf.edu/tid/gnc64f00.

70. Bils J. Management Summary. Salem King Menthol Delivery pgt (mdd \#88-31214): RJ Reynolds, 1988. http://legacy.library.ucsf.edu/tid/nzm83d00

71. Daniel HG, Walk EM. R\&D Review on Menthol: Philip Morris, 1980. http://legacy. library.ucsf.edu/tid/tum64e00.

72. Klausner K. Menthol cigarettes and smoking initiation: A tobacco industry perspective. Tobacco Control 2011;20(Suppl 2):ii12-ii19.

73. Anderson SJ. Menthol cigarettes and smoking cessation behavior: A review of tobacco industry documents. Tobacco Control 2011;20(Suppl 2):ii49-ii56.

74. Miller GE, Jarvik ME, Caskey NH, et al. Cigarette mentholation increases smokers' exhaled carbon monoxide levels. Exp Clin Psychopharmacol 1994;2:154-60.

75. Wagenknecht LE, Cutter GR, Haley NJ, et al. Racial differences in serum cotinine levels among smokers in the coronary artery risk development in (young) adults study. Am J Public Health 1990;80:1053-6.

76. Gardiner $\mathbf{P}$, Clark P. Menthol in cigarettes: it helps the poison go down easier. 2nd Conference on Menthol Cigarettes. Washington, DC, 2009.

77. Silverstein B, Feld S, Kozlowski LT. The availability of low-nicotine cigarettes as a cause of cigarette smoking among teenage females. J Health Soc Behav 1980;21:383-8. 